(6)

\section{OPEN ACCESS}

'Pneumology Department, Hospital de Braga, Braga, Portugal

${ }^{2}$ Pathology Department, Hospital de Braga, Braga, Portugal

\section{Correspondence to}

Dr Raquel Pereira, raquel.pereira14@gmail.com

Accepted 23 February 2019

\title{
Leser-Trélat sign in metastatic melanoma to pleura
}

\author{
Raquel Pereira, ${ }^{1}$ Sofia Daniela Carvalho, ${ }^{2}$ João Filipe Cruz ${ }^{1}$
}

\section{DESCRIPTION}

Metastatic melanoma is an uncommon and aggressive form of cutaneous neoplasm, presenting a very high mortality rate. The presentation with pleural metastasis and pleural effusion is extremely rare, with about $5 \%$ of cases. ${ }^{1-3}$

The Leser-Trélat sign is considered a paraneoplastic cutaneous marker of internal malignancy. Here, we describe a case of pleural effusion presenting as an first manifestation of metastatic malignant melanoma in association with LeserTrélat signal. ${ }^{4-6}$

A 71-year-old non-smoking woman, with a history of diabetes mellitus type 2, arterial hypertension and ischaemic cardiomyopathy with moderate left ventricular dysfunction and coronary disease.

She was admitted to our hospital due to progressive worsening dyspnea with a week of evolution, with right thoracalgia of pleuritic characteristics and easy fatigue. She referred a rapidly evolving appearance in the last 3 months of hyperchromic lesions on the right posterior thoracic region, pruritic, which were increasing in number and size, and a right axillary lymphadenopathy.

On admission to the emergency department, she was polypneic with signs of respiratory distress, tachycardic, normotensive and afebrile. Chest

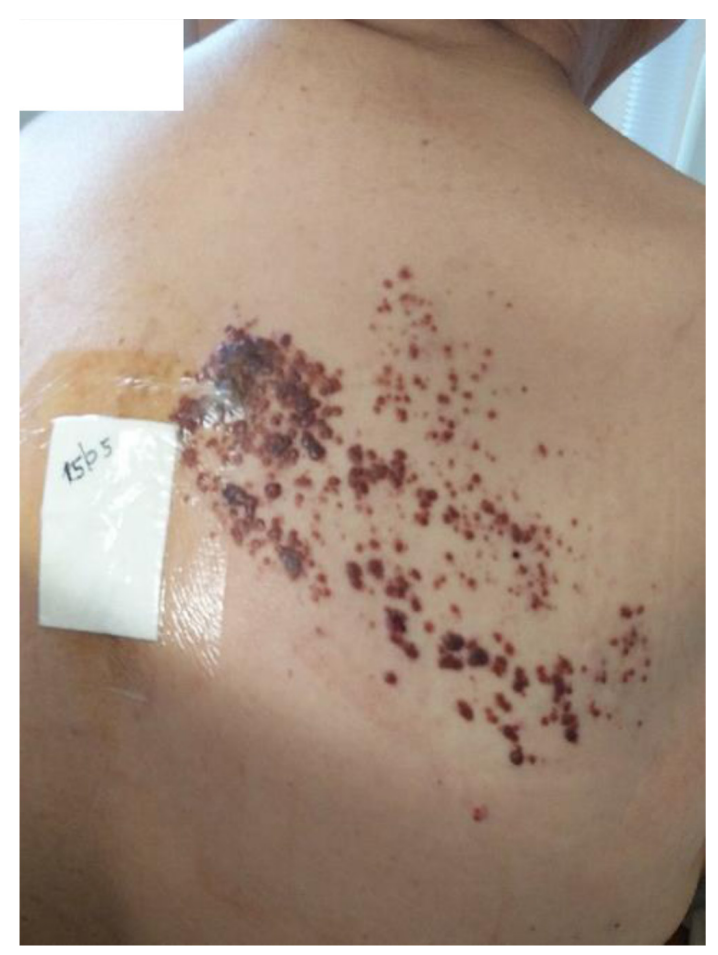

Figure 1 Clinical presentation of multiple seborrheic keratoses on the right posterior thoracic region.

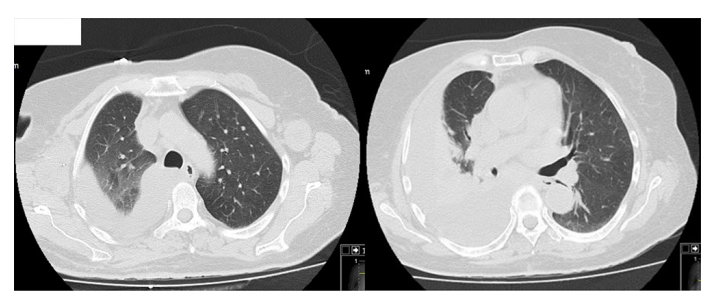

Figure 2 Chest CT showing bilateral axillary lymphadenopathies, occlusion of the lumen of the bronchi to the right lower lobe and middle lobe and a large pleural effusion on the right side.

auscultation revealed absence of breath sounds in the right hemithorax. No signs of digital clubbing were found. Dermatological examination revealed maculopapular lesions of violet-brown colour on right posterior thoracic region, grouped in plates, pruritic, at different evolution stages, diagnosed as seborrheic keratosis (figure 1).

Blood test showed high $\mathrm{C}$ reactive protein $(129 \mathrm{mg} / \mathrm{dL}$, normal: $<2.9 \mathrm{mg} / \mathrm{dL})$, leucocytosis $13800 \times 10^{9} / \mathrm{L}$, negative biological markers for myocardial necrosis, high brain-type natriuretic peptide $2678 \mathrm{pg} / \mathrm{mL}$ (normal: $500 \mathrm{pg} / \mathrm{mL}$ ). Other laboratory data were unremarkable.

Arterial blood gas analysis showed severe hypoxaemic respiratory insufficiency.

ECG showed sinus rhythm, with infra-ST in precordial leads and T-wave inversion in V6.

Chest radiography revealed a large right-sided pleural effusion. A chest, abdominal and pelvic CT revealed bilateral axillary lymphadenopathies, occlusion of the lumen of the bronchi to the right lower lobe and middle lobe and a large pleural effusion on the right side (figure 2), without other alterations.

Non-invasive ventilation and medical therapy were initiated, although with slow and gradual improvement of the patient's respiratory status.

She was submitted to diagnostic and evacuation thoracentesis, with drainage of $1500 \mathrm{~mL}$ of serum-haematic pleural fluid. Pleural fluid analysis revealed an exudate with 59\% lymphocytes, glucose $233 \mathrm{mg} / \mathrm{dL}$, lactate dehydrogenase $226 \mathrm{U} / \mathrm{L}$ and total protein $4.1 \mathrm{~g} / \mathrm{dL}$. Cytology of pleural fluid was negative for neoplastic cells.

Flexible bronchoscopy showed a slight extrinsic compression of the right lower lobe, in basal segments, probably related to pleural effusion, with no other endobronchial changes. The cytology of bronchial aspirate was negative for neoplastic cells.

Pleural biopsy was performed, with histological examination showing a malignant neoplasia 
composed of epithelioid cells, with diffuse expression of Melanocyte Inducing Transcription Factor (MiTF).

Biopsy of the right axillary lymph node with immunohistochemical study revealed a differentiated malignant neoplasm compatible with malignant melanoma.

Based on the above findings, the patient was diagnosed with malignant melanoma with pleural metastasis associated with Leser-Trélat signal.

The patient's medical condition rapidly declined and she ultimately succumbed to death before initiation of any therapy.

\section{Learning points}

- Our case underlines the importance to consider metastatic melanoma in differential diagnosis, especially in dark effusion.

- Metastatic pleural melanoma is rare and the association with Leser-Trélat sign is even rarer, and a high index of suspicion in these cases is crucial for rapid diagnosis and prompt treatment, in order to avoid an unfavourable outcome.

Contributors RP wrote the manuscript with support from SDC and JFC. All authors discussed the results and contributed to the final manuscript.
Funding The authors have not declared a specific grant for this research from any funding agency in the public, commercial or not-for-profit sectors.

Competing interests None declared.

Patient consent for publication Obtained.

Provenance and peer review Not commissioned; externally peer reviewed.

Open access This is an open access article distributed in accordance with the Creative Commons Attribution Non Commercial (CC BY-NC 4.0) license, which permits others to distribute, remix, adapt, build upon this work non-commercially, and license their derivative works on different terms, provided the original work is properly cited and the use is non-commercial. See: http://creativecommons.org/ licenses/by-nc/4.0/

\section{REFERENCES}

1 Agarwal P, Nambiyar K, Manju Kaushal, et al. Primary malignant melanoma of pleura: a case report and literature review. Diagn Cytopathol 2016;44:648-52.

2 De Vita F, Giordano G, Fabozzi A, et al. Metastatic melanoma: an unusual presentation. Tumori 2011;97:130-2.

3 Mohan KM, Gowrinath K. Unusual thoracic manifestation of metastatic malignant melanoma. Lung India 2010;27:96-8.

4 Siedek V, Schuh T, Wollenberg A. Leser-Trelat sign in metastasized malignant melanoma. Eur Arch Otorhinolaryngol 2009;266:297-9.

5 Fanti PA, Metri M, Patrizi A. The sign of Leser-Trélat associated with malignant melanoma. Cutis 1989;44:39-41.

6 Ellis DL, Kafka SP, Chow JC, et al. Melanoma, Growth Factors, Acanthosis Nigricans, the Sign of Leser-Trélat, and Multiple Acrochordons. N Engl J Med Overseas Ed 1987;317:1582-7

Copyright 2019 BMJ Publishing Group. All rights reserved. For permission to reuse any of this content visit https://www.bmj.com/company/products-services/rights-and-licensing/permissions/

BMJ Case Report Fellows may re-use this article for personal use and teaching without any further permission.

Become a Fellow of BMJ Case Reports today and you can:

- Submit as many cases as you like

- Enjoy fast sympathetic peer review and rapid publication of accepted articles

- Access all the published articles

- Re-use any of the published material for personal use and teaching without further permission

For information on Institutional Fellowships contact consortiasales@bmjgroup.com

Visit casereports.bmj.com for more articles like this and to become a Fellow 